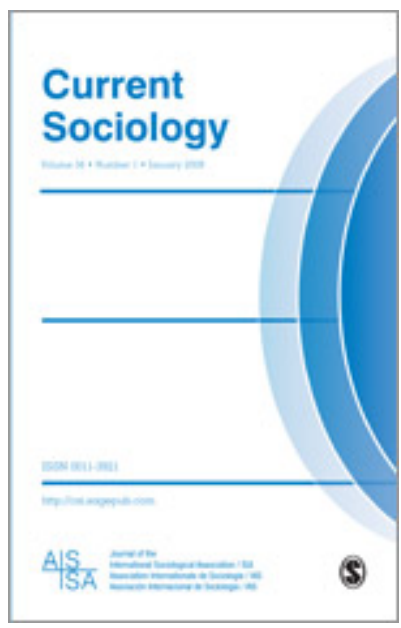

\title{
Superdiversity and social policies in a complex society: Social challenges in the 21 st century
}

\begin{tabular}{|c|l|}
\hline Journal: & Current Sociology \\
\hline Manuscript ID & CS-19-0227.R1 \\
\hline Meywords: & $\begin{array}{l}\text { superdiversity, migration, social changes, social complexity, social policy, } \\
\text { social work }\end{array}$ \\
\hline Abstract: & $\begin{array}{l}\text { Superdiversity is a characteristic of contemporary societies that affects } \\
\text { processes of social change and social policies. Using meta-analysis } \\
\text { methods, this article reviews how superdiversity is addressed in the } \\
\text { literature to better inform social policies from a sociological perspective. } \\
\text { A search of the literature in English and Spanish revealed 76 articles } \\
\text { using different methodological approaches over the period 2007-2019. } \\
\text { The descriptors for the search were superdiversity, cultural diversity, } \\
\text { migratory flows, global migration, population change, social interactions, } \\
\text { social change, social complexity, social care, social policy, superdiverse } \\
\text { contexts, age, gender, and migrants/superdiversidad, diversidad } \\
\text { cultural, flujos migratorios, migración global, cambio de población, } \\
\text { interacciones sociales, cambio social, complejidad social, cuidados, } \\
\text { política social, contextos superdiversos, edad, género, and migrantes. } \\
\text { The main results are the identification of key aspects to inform social } \\
\text { policies and promote sustainable social change consonant with the } \\
\text { current social reality. }\end{array}$ \\
\hline
\end{tabular}

\section{SCHOLARONE Manuscripts}




\title{
Superdiversity and social policies in a complex society: Social challenges in the 21 st century
}

\begin{abstract}
Superdiversity is a characteristic of contemporary societies that affects processes of social change and social policies. Using meta-analysis methods, this article reviews how superdiversity is addressed in the literature to better inform social policies from a sociological perspective. A search of the literature in English and Spanish revealed 76 articles using different methodological approaches over the period 20072019. The descriptors for the search were superdiversity, cultural diversity, migratory flows, global migration, population change, social interactions, social change, social complexity, social care, social policy, superdiverse contexts, age, gender, and migrants/superdiversidad, diversidad cultural, flujos migratorios, migración global, cambio de población, interacciones sociales, cambio social, complejidad social, cuidados, politica social, contextos superdiversos, edad, género, and migrantes. The main results are the identification of key aspects to inform social policies and promote sustainable social change consonant with the current social reality.
\end{abstract}

Keywords: superdiversity; social work; migration; social changes; social complexity

\section{Introduction}

Superdiversity refers to multiple sources of diversity, such as religious, social, cultural, educational, economic, or gender diversity, as well as age and country of origin, among others. For example, superdiversity does not come just from the country of origin, but also gender (e.g. black males versus black females; white females versus black females, etc.) or age (old people who engage - or not - with the younger generations) (Trienekens \& Groot, 2016: 89). In increasingly complex contemporary societies with a higher population diversity than ever before, the concept of 
superdiversity has descriptive, methodological, and practical applications. In this regard, superdiversity can be considered a successor to multiculturalism (Alba \& Duyvendak, 2019:6). Superdiverse environments influence our actions and the way we describe ourselves. In this regard, superdiversity enhances our own self-understanding and feelings to gain a better understanding of the "other." However, it can also reinforce the bubble in which we live, by generating a situation of estrangement with respect to the others who inhabit our world, but who are very distant from us (Hochschild, 2016: 40). This situation should be taken into account in the definition of social policies and goals in order to adapt them to the current social reality.

Since Vertovec first coined the term and developed the concept of superdiversity in 2007, several scholars have conducted research in this field. The main objective of this article is to analyse the key papers on the subject of superdiversity published from 2007 to 2019. We focus on the theoretical discussions, practical experiences, and key areas of interest that are being redefined in the framework of superdiversity.

Additionally, this research examines policies that can be redefined as a consequence of these multiple and diverse societies.

In sociology, as in other disciplines, meta-analysis is a well-founded research technique (Lundahl \& Yaffe, 2007:52; Ramsey \& Montgomery, 2014:76), which permits addressing the new characteristics of social policies in superdiverse settings and the main debates that arise within our field of knowledge.

This article is organised as follows. Section 2 describes the methodology used in the meta-analysis, the coding procedure, the bibliometric study, and the papers selected for review. Section 3 presents the research results. Finally, conclusions are drawn and several limitations of the work are discussed. 


\section{Methodology}

Superdiversity is a research area in sociology and the social sciences with a growing scientific community. This meta-analytical review examines articles on superdiversity in the fields of sociology, social policy, and social work.

Meta-analysis is based on two types of bibliometric indicators, performance and quality indicators and relational bibliometric indicators.

- $\quad$ Performance and quality indicators are traditional indexes used in metaanalysis research. They include number of citations (average citations, sum, minimum, maximum citations), most cited papers, complex metrics (e.g. h-index, g-index, hgindex, and $\mathrm{q}^{2}$-index), co-authorship analysis, and visibility and impact indicators. Scientific databases such as the Web of Science are used to obtain the data needed to calculate these indicators.

- $\quad$ Relational bibliometric indicators are mapping techniques where the results obtained are presented in graphical form. Scientific maps are obtained from the information using clustering analysis (e.g. the simple centres algorithm, single or complete linkage, average linkage and sum linkage clustering algorithms). To obtain the results, network analysis (Callon's density and centrality), temporal analysis, and longitudinal analysis are used. Science mapping analysis is conducted using specific software (e.g. SciMAT, VOSViewer, etc.) that provides spatial representations of the relations among scientific specialties in the form of maps (co-authorship analysis, coword analysis, bibliographic coupling, conceptual and cognitive analysis, etc.). This technique facilitates the study of collaborations among researchers, institutions, and countries. 
This review is based on both performance and quality indicators and relational bibliometric indicators, which is one of the main contributions of the study.

We have selected 76 papers published over the period 2007- 2019 from the Web of Sciences. The inclusion criteria were (a) articles written in English and Spanish published from 2007 to 2019 and (b) studies related to superdiversity, as the term was first coined in 2007.

The initial search aimed to find all articles which specifically included in their abstracts, keywords, or titles the term "superdiversity", together with the terms "cultural diversity", "migratory flows", "global migration", "population change”, “social interactions", "social change", “social complexity", “social care”, "social policy”, "superdiverse contexts", "age", "gender", and "migrants". ${ }^{1}$ The exclusion criteria were based on the assumption that if none of these terms appeared in any of these sections, it was likely that the concept did not occupy a core position in the study, and the article could therefore be excluded. Papers on linguistics were also omitted as this review does not focus on linguistic differences and their consequences, but rather the fields of sociology, social policies, and social work. Likewise, articles on sports, folklore, or music were not included as they are beyond the scope of this review. Following a subsequent deep reading of the articles, 10 additional articles were eliminated. Finally, the search results included several articles on diversity that were also excluded. Table 1 describes the search strategy and process.

\footnotetext{
${ }^{1}$ The terms in Spanish were superdiversidad, diversidad cultural, flujos migratorios, migración global, cambio de población, interacciones sociales, cambio social, complejidad social, cuidados, política social, contextos superdiversos, edad, género and migrantes.
} 
Figure 1. Search strategy and process

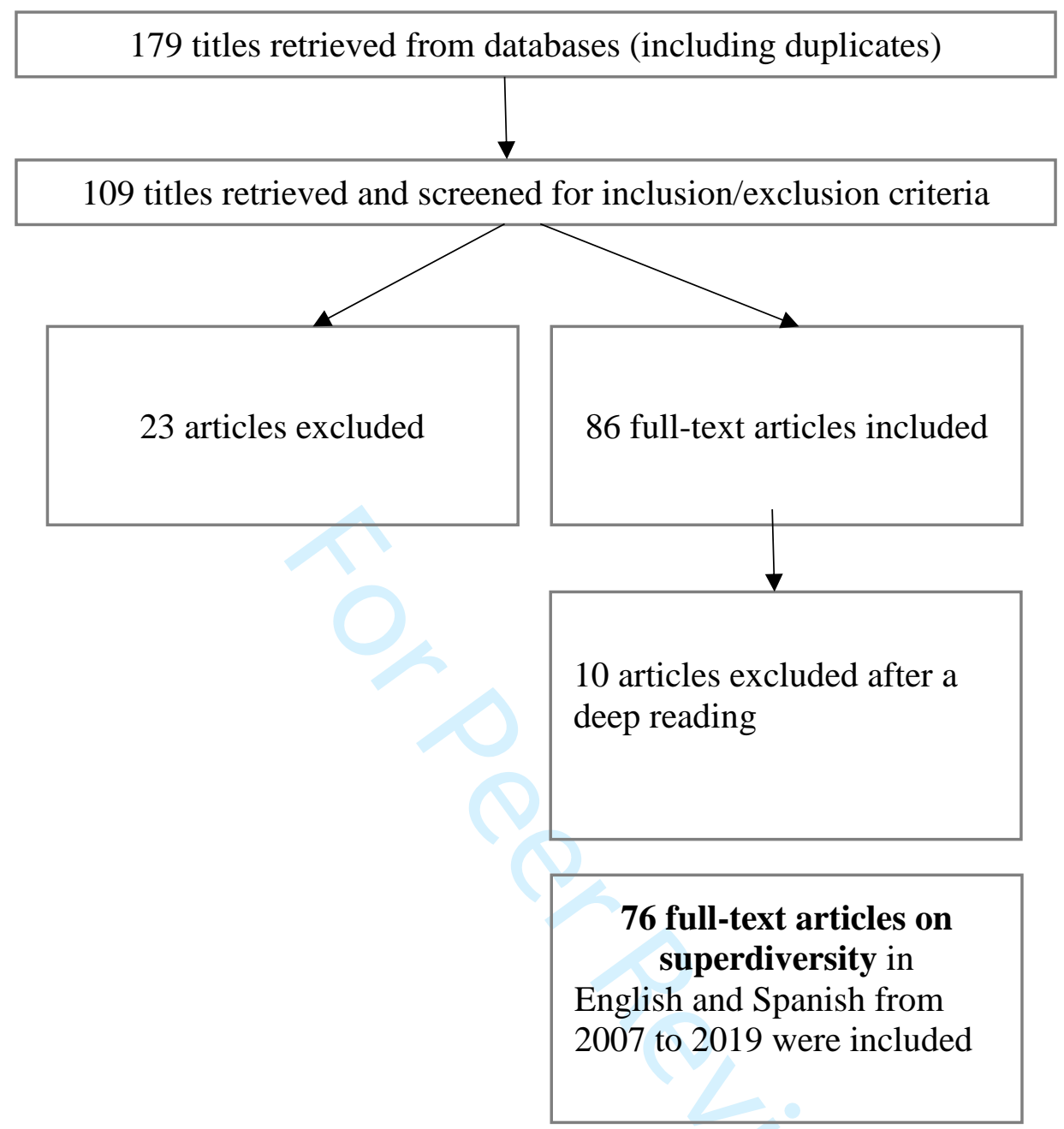


A manual search was conducted in May 2019 of papers published from 2007 to 2019 in the selected journals. The studies were coded by reading the abstracts and full texts of the papers. Flow software was used to codify and work with the papers. Additionally, the relationships among papers were analysed using VOSViewer software. An optimisation algorithm was used to identify relationships between authors, co-authorships, citations, and bibliographic coupling in the papers included in the review.

\subsection{The coding procedure}

In order to structure the selected papers by level of evidence, the Oxford Centre for Evidence-Based Medicine - Levels of Evidence (OCEBM, 2011) was applied. The CEBM Levels of Evidence is an approach to systematise the classification of empirical research according to five levels of bias control as follows:

- $\quad$ Level 1 (L1): High-quality systematic reviews

- $\quad$ Level 2 (L2): Randomised clinical trials

- $\quad$ Level 3 (L3): Case-control trials without randomisation

- $\quad$ Level 4 (L4): Case reports

- $\quad$ Level 5 (L5): Studies based solely on expert opinions

The OCEBM grading system is regularly applied in assessing the methodological quality of studies related to the field of social work (Moorhead et al., 2013:61).

The research methods used in the corresponding papers were also categorised as qualitative, quantitative, and mixed research, while the research type options were specified as quantitative (regression analysis, descriptive analysis) or qualitative (case 
study, theoretical articles, experiments, narrative summary). According to our data, $95 \%$ of the papers selected can be classified as research based on a qualitative system of analysis (Table 1). 
Table 1. Articles published by types of research

Insert Table 1 here

\begin{tabular}{|lrr|}
\hline Types of research & Total & $\%$ \\
\hline Qualitative & 72 & $95 \%$ \\
\hline Mixed & 4 & $5 \%$ \\
\hline Total general & 76 & $100 \%$ \\
\hline
\end{tabular}




\subsection{Bibliometric study}

In order to assess the research, bibliometric aspects were included to provide an idea of the quality of the study and identify the reliability of the sources and the countries where superdiversity is an important topic (Franklin, Kim \& Tripodi, 2009:32; Martínez, Herrera, Contreras, Ruiz, \& Herrera-Viedma, 2015:56; Chan, 2016:23). Hence, the selected publications were analysed by year of publication, the country of the author or authors, the journal where they were published, and the journal's impact.

\subsubsection{Papers by year}

During the period analysed, superdiversity was found to be a salient research topic in the field. The evolution of publications is shown in Figure 2. 
Figure 2. Articles published by year

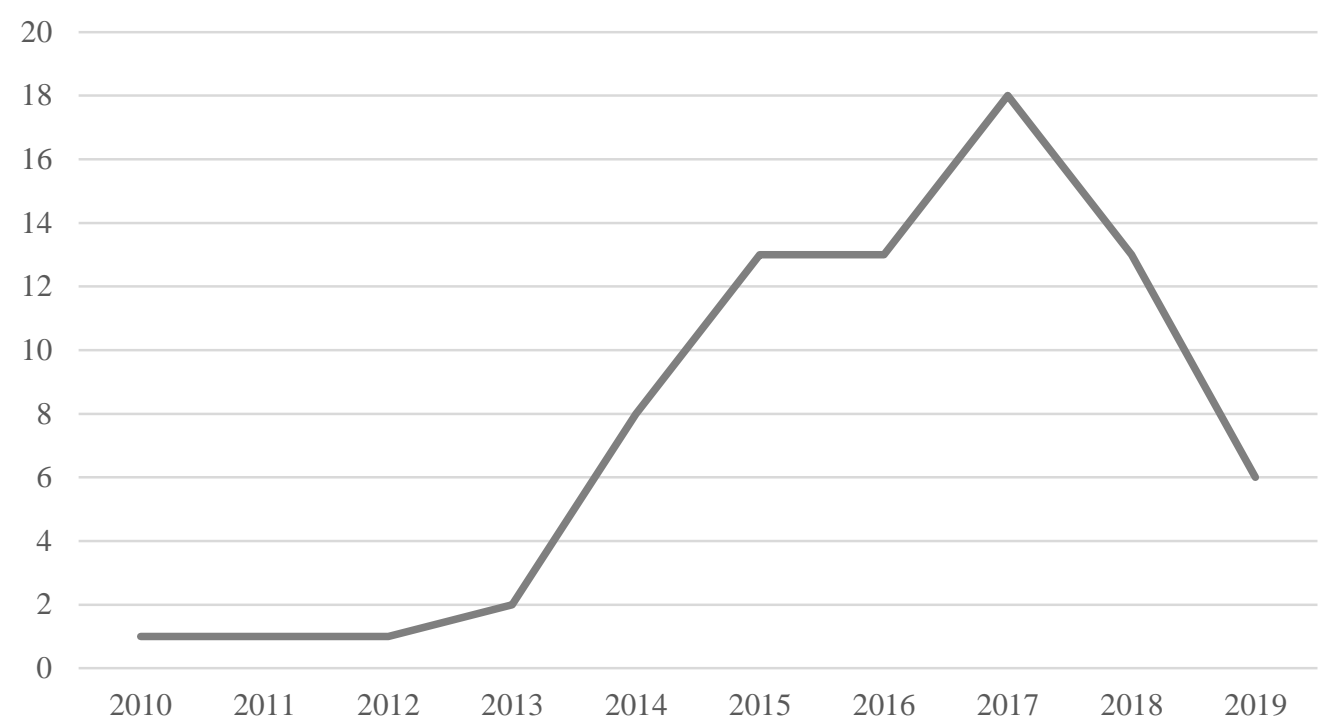


As can be observed in Figure 2, most of the papers retrieved were published from 2015 to 2019 (63 papers, $82.89 \%$ ), with the largest number of papers published in 2017 (18 papers, $23.68 \%$ ).

\subsubsection{Papers by country in the period 2007-2019 $(n=76)$}

Concerning the place of publication, the United Kingdom published the largest number of scientific articles, followed by the Netherlands and Belgium. These three countries have a large immigrant population, which could explain the research interest in superdiversity. Together, the three countries account for $57 \%$ of all publications. However, it is also striking that the total number of publications from other EU member states remains quite high (18\%). A small number of non-EU countries (8) were also found to have published highly-cited articles addressing superdiversity. 
Table 2 . Articles published by country

\begin{tabular}{lrc} 
Country & Total & \% \\
\hline Australia & 3 & $4 \%$ \\
Austria & 1 & $1 \%$ \\
Belgium & 8 & $11 \%$ \\
Brazil & 2 & $3 \%$ \\
Canada & 1 & $1 \%$ \\
Chile & 1 & $1 \%$ \\
China & 1 & $1 \%$ \\
Slovakia & 1 & $1 \%$ \\
Germany & 5 & $7 \%$ \\
Italy & 3 & $4 \%$ \\
Luxembourg & 2 & $3 \%$ \\
Netherlands & 11 & $15 \%$ \\
New Zealand & 1 & $1 \%$ \\
Portugal & 3 & $4 \%$ \\
Spain & 1 & $1 \%$ \\
Sweden & 1 & $1 \%$ \\
Switzerland & 1 & $1 \%$ \\
United Kingdom & 24 & $32 \%$ \\
United States & 6 & $8 \%$ \\
\hline Total general & $\mathbf{7 6}$ & $\mathbf{1 0 0 \%}$
\end{tabular}




\subsubsection{Papers by author}

With regard to authorship, a few authors have published more than one paper in this field. More specifically, Phillimore published five papers and was the most cited author. In addition, two authors published two articles each: Meissner and Crul. Additionally, several authors referred to the research of Sepulveda et al. (2011:82). As regards co-authorship, several of Phillimore's and Padilla's articles on superdiversity were published in collaboration with other authors in the field. The authors and their coauthors are shown in Figure 3. 
Figure 3. Co-authorships among the selected papers 
Figure 4 shows the linkages between authors, while figures 5 and 6 represent the bibliographic coupling and shared citations. The items are labelled and represented by a circle in all the figures: the larger the circle, the larger the weight of that item. In addition, the relationships among items are shown in different colours that represent the clusters in which an item is included. The distance between two papers in the network visualisation indicates the relationship between them such that the closer the papers, the stronger their relatedness.

The linkages among articles shown in Figure 4 correspond to the citations included in each study. Sepulveda (2011:82) is the most cited author in the papers reviewed, followed by Boccagni (2015:19), Meissner (2015:59), and Phillimore (2015:71). Accordingly, these authors are represented by the largest circle next to their names. 
Figure 4. Citations

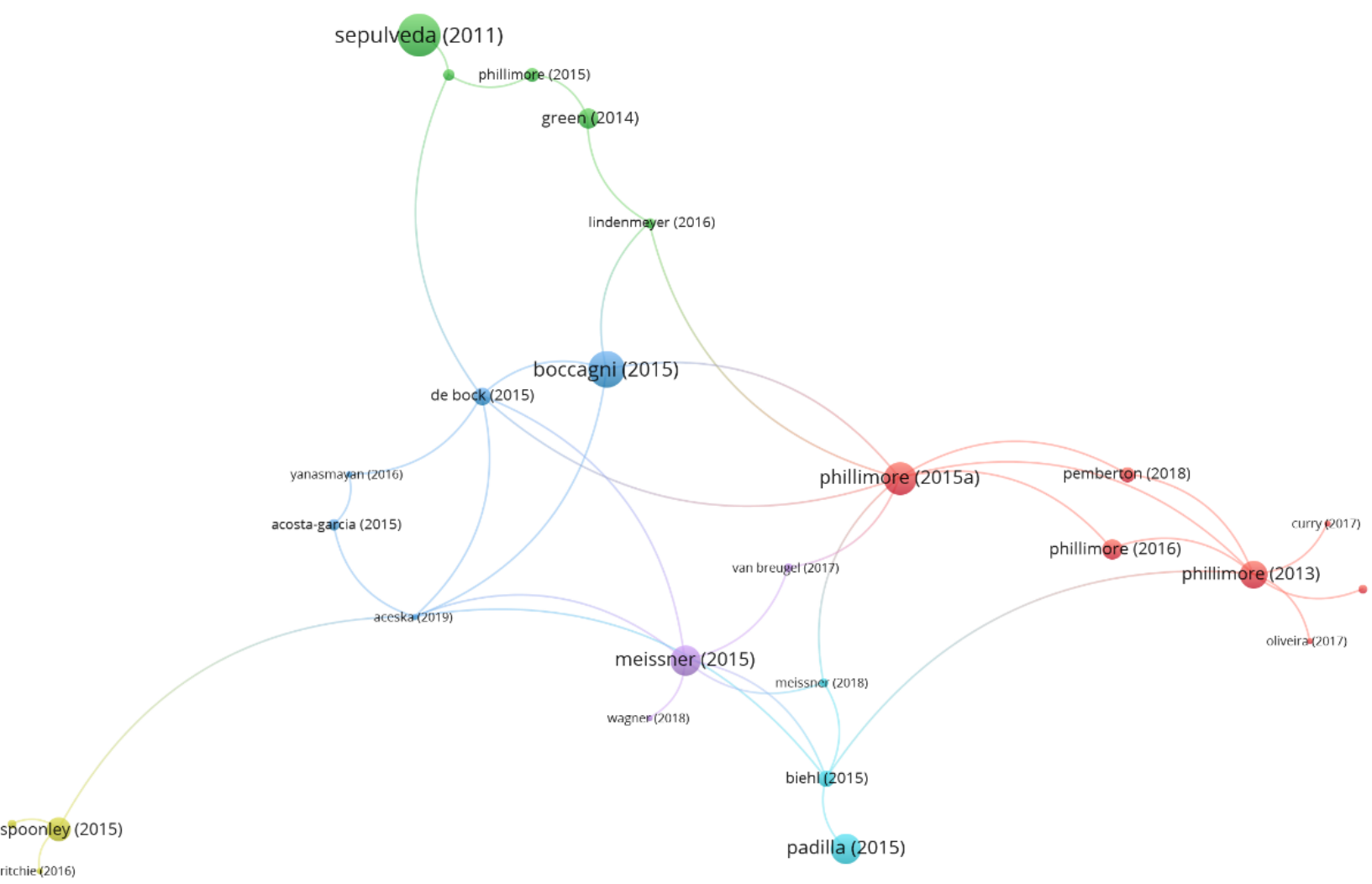




\section{Page 17 of 44}

Figure 5. Bibliographic coupling

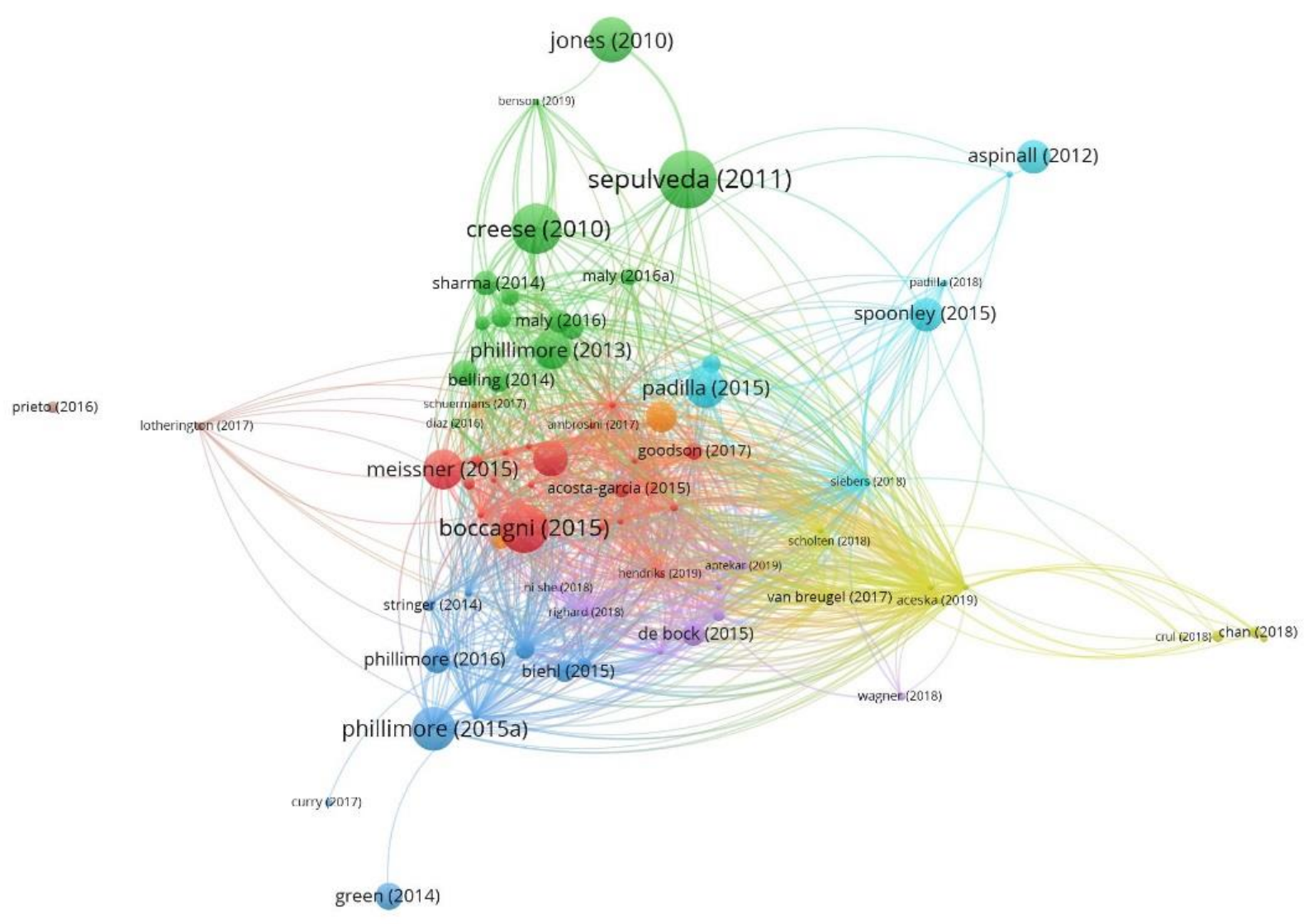

含 vosviewer 
Figure 6. Co-citations

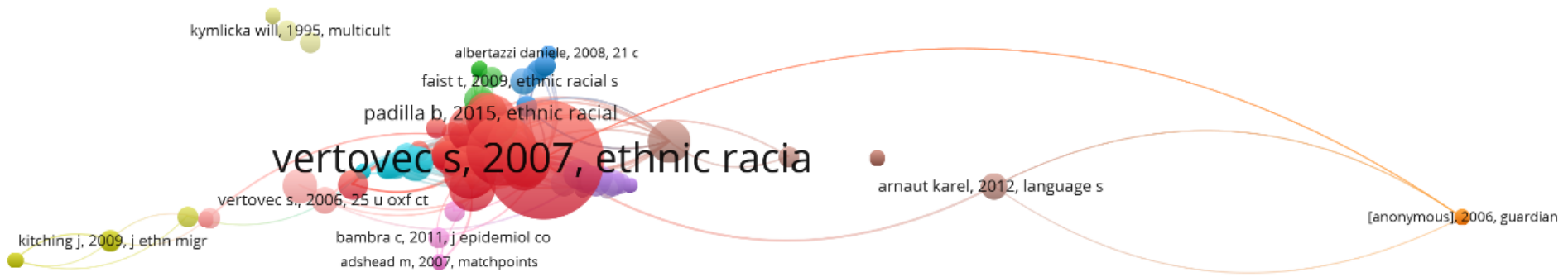

fis vosviewer 
Finally, Figure 6 indicates the relevance of Vertovec (2007:94), the author who coined the term and defined the concept of superdiversity. For that reason, and given the impact of his publication "Super-diversity and its implications", Vertovec can be considered "the father of superdiversity".

\subsubsection{Papers by journal, Google Scholar Citations and the JCR ranking}

This section describes the most cited articles not just among the papers included in the revision, but also in other research published in the field. Although 36\% (27) of the papers were published in three JCR journals, it should also be noted that almost $65 \%$ of the highly-cited papers were published in two of the most longstanding journals: Policy and Politics and Ethnic and Racial Studies.

The fact that a journal dedicated to the dynamics of policy-making leads the number of publications confirms the interest of analysing the effect of superdiversity on policies definition.

On the other hand, several of the most cited papers were not published in the highest ranked journals according to the JCR ranking. Moreover, papers published in Q1 journals do not have many citations (e.g. Lindenmeyer et al., 2016:49).

The most cited paper in Google Scholar is "Population superdiversity and new migrant enterprise: The case of London" (Sepulveda et al., 2011:82), which was cited a total of 104 times. The second most cited article was "Delivering maternity services in an era of super diversity: the challenges of novelty and newness" (Phillimore, 2015:71), which studied the situation of migrant mothers in terms of access to maternity services (75 citations). 
The remaining papers deal mostly with topics such as educational initiatives, social work education or social pedagogy methods (56\%), tools for practitioners, issues related to learning and training strategies, and educational programs focusing on children.

Additionally, no differences were found between topics by country, with the exception of the United States, which has produced more scientific literature on practical experiences for modelling programmes and model applications. Finally, there is a predominance of research concerning social media in social work intervention in the other countries.

\section{Topics of interest}

In order to classify and structure the topics analysed in the selected articles, the RAKE method (Rapid Automatic Keyword Extraction from individual documents) was used. This method is based on an algorithm that detects the most frequently used words. These keywords were obtained from the abstracts of the selected papers.

Table 3 shows the keywords extracted by RAKE in the corresponding order of importance. 
Table 3. Keywords

\begin{tabular}{|c|}
\hline Keywords \\
\hline Diversity \\
\hline Inequality \\
\hline Migration \\
\hline Workers \\
\hline Integration \\
\hline Migrants \\
\hline Governance \\
\hline Practices \\
\hline Dynamics \\
\hline
\end{tabular}


As mentioned above, the terms "migration" and "migrants" are considered as keywords.

On the other hand, "governance" and "practices" may refer to the public policies identified in the analysis, while "inequality" is related to social policies and the inclusion of migrants. However, there are not many references to superdiversity from the viewpoint of longevity and the ages of people living in the same social context.

\section{Results}

The selected articles were analysed in terms of the origins of superdiversity and the policies that could be redefined in consonance with a superdiverse context.

Firstly, it should be highlighted that most of the papers addressed diversity in terms of citizens' nationality. In this line, two of the most frequent keywords in these articles were precisely "migrants" and "migration". Nevertheless, the researchers also examined religious diversity, gender diversity, and economic diversity. Within the superdiversity framework, these are the factors that lend this status of greater diversity and produce a synergistic effect, while cultural factors and educational level are other relevant causes that have been identified in the literature.

Secondly, regarding the above policies, a recurring multidimensional perspective was observed in core welfare services (health care and education), urban governance, and employment strategies affected by superdiversity.

When classifying the articles according to the OCEBM system, most were found to use a qualitative methodology $(95 \%)$ without samples $(\mathrm{n}=35 ; 46 \%)$. As regards sampling methods, only a small percentage of the total qualitative research used randomised samples $(\mathrm{n}=8 ; 10.5 \%)$. 


\subsection{Methodologies used in the papers}

Most papers were case studies and hence employed a qualitative approach. Nevertheless, some quantitative research has also been conducted in recent years (e.g. Phillips \& Webber, 2014:74; Curry et al., 2017:27; Wekker, 2019:96). Quantitative methods are useful for identifying the key points of superdiversity. Concerning the methodology used in the papers, it is also important to highlight that, where appropriate, the interviews were conducted in migrants" "mother tongue" (Pemberton \& Phillimore, 2018:69, p. 740).

\subsection{Factors that determine the emergence of superdiversity}

Superdiversity understood in the sense of Vertovec (2007:94) emerges provided that a supracategory is concentrated in previously diverse spaces as the result of influences that produce a synergistic effect. The effect is a "living" diversity, which feeds on itself with concausality. An analysis of the superdiversity research shows how this concept is utilised in a variety of fields from Somalis who undertake an economic activity in a European city to networks with digital texts that serve as a meeting point for immigrants, a prison, Chinese immigrants, or social workers, among others. The environments are varied, but the underlying phenomenon is the same. In this sense, superdiversity implies increasing diversity within diversity (Geldorf et al., 2017:34)

The meta-analysis highlights a group of factors relevant to this interinfluence: race, physical spaces of settlements, cultural influences, the correct use of the new language, economic level, and religion. Regardless of immigrants' own cultures, ways of life, and customs, which they tend to preserve in the host countries, it is precisely this interinfluence that is at the basis of superdiversity. According to this body of papers, a recurrent characteristic is the coexistence of people of very different origins and cultures 
in cities, neighbourhoods, or other environments. Consequently, in most of the cases analysed, the principal source of diversity is the country of origin (migration). Nevertheless, Goodson and Grzymala-Kazlowska (2017:36) recommend a more participatory and multidimensional methodology that includes levels of sociodemographic complexity associated with complex populations. Therefore, legal rights, gender issues, power relations, and educational level are aspects that should be taken into account when analysing superdiversity and designing strategies to manage superdiverse environments. For social policies, and for social intervention practitioners, including such aspects may allow for a better diagnosis of superdiverse environments, as well as a better design of intervention measures. The presence of these aspects in different research studies is shown in tables 1 and 2 of the appendices.

\subsection{The usefulness of the superdiversity concept}

The methodological lens of superdiversity can aid in improving the implementation of social policies in disadvantaged groups. New research approaches must take into account the practical utility of superdiversity. In this regard, this analysis has detected the inclusion of superdiversity-based policies to improve access to welfare state services.

Regarding urban policies, migrants should not be located in "urban margins" which limit their possibilities (Aceska et al., 2019:2; Aptekar, 2017:8). According to several authors, superdiversity has strong implications for urban public spaces as it affects how people understand differences (Wilson, 2011:98), enjoy public spaces in a way that leads to increased tolerance (Neal et al., 2015:62), negotiate differences (Neal et al., 2015:62), or perceive diversity as an unremarkable fact of everyday life (Wessendorf, 2014:97; Jones et al., 2015:43) 
Austerity policies and the scarcity of resources affect migrants in a very significant way, giving rise to new inequalities (Berg, 2018:16). Moreover, both formal and informal barriers can be created that hinder access to services (López Peláez \& Gómez Ciriano, 2019:50).

Education policy proposals to adapt science teachers to cater to changes related to the multiple religions of their students are also relevant (De Carvalho, 2016:29; Poole, 2016:75; Billingsley, 2016:18)

Based on research with teachers and students at a Dutch university, Siebers (2018:84) questioned the relevance of superdiversity in the actual reality of those who experience it. According to the author, the main concerns of students had to do with conviviality, creolisation, ethnic boundaries, and groupism rather than superdiversity. In a similar line, Padilla et al. (2018:68) studied superdiversity and conviviality jointly.

In summary, superdiversity contributes in two ways to migrant integration. First, by reflecting upon the potential of intercultural policies to respond to superdiverse societies and second, by engaging with the dominant idea driving the adoption of intercultural policies and the idea that (super)diversity has to be harnessed for other economic and integration ends (Abdou \& Geddes, 2017:1)

\section{Conclusions}

This article has summarised the evidence on superdiversity through a review of the literature on the topic published from 2007 to 2019. The main results show that the incorporation of multiple sources of diversity has led to social changes that should be considered when defining public policies. An analysis of the papers has revealed policies related to country and ethnic groups, urban margins, cultural issues, language issues, the economic situation of citizens, religions, social classes, legal rights, gender, 
education, housing, and transmigration. In this regard, five policy areas have been identified: economic and employment policies; health policies; social and care policies; educational policies; and cultural and urban policies. Consequently, public policies in these areas should be revised and rethought in order to include a superdiversity approach. The policies applied in the articles analysed in this review should serve to open a new path of reflection and mixed policy research. Combined social policies that consider the interrelated causes of superdiversity are needed to address and understand this new and complex scenario based on social movements. In this vein, an interesting line of future research would be the integration of ethnic minorities and their economic development.

With regard to the methodology used, most papers were based on qualitative analyses, while the use of quantitative samples was infrequent. Nevertheless, the analysis has underlined the importance of additional factors related to superdiversity beyond differences between migrant groups. Aside from migratory superdiversity, superdiversity can also be associated with longevity, cultural differences, the labour market, and gender issues. The articles reflect the state of the art of an emerging research area with a large percentage of case studies and thematic analyses based on qualitative methods and approaches. But what makes this research field exceptional is the application of mixed quantitative methods, which are also systematically supported by statistics. Indeed, quantitative studies of these superdiverse scenarios would contribute to our understanding of superdiversity from a different perspective, while the design of social policies can also be enriched through a broad approach to this phenomenon. 
This review has some limitations. First, some grey literature, such as reports by non-governmental organisations and the reflections of frontline practitioners were not included. Second, only studies in English and Spanish were reviewed. In spite of these limitations, this study has reviewed the leading journals in the social sciences field which constitute a very significant sample of the literature on superdiversity. Our results should help to define social policies and goals that are better aligned with the current social reality. Indeed, the superdiversity of our societies calls for an interdisciplinary approach that allows us to effect the necessary changes in the economic, education, health, urban planning, and social services fields, all of which are affected by this phenomenon. Not only have problems and new demands of citizens emerged in these superdiverse environments, but also problems of coordination and collaboration between others, making it necessary to build bridges that reach beyond social bubbles and radicalisation processes in both the physical and digital environment (Alava, FrauMeigs, \& Hassan, 2017:5). 


\section{References}

1. Abdou, L. H., \& Geddes, A. (2017). Managing superdiversity? Examining the intercultural policy turn in Europe. Policy \& Politics, 45(4), 493-510.

2. Aceska, A., Heer, B., \& Kaiser-Grolimund, A. (2019). Doing the city from the margins: Critical perspectives on urban marginality. Anthropological Forum, 1-11.

3. Acosta-García, R., \& Martínez-Ortiz, E. (2015). Mexico through a superdiversity lens: Already-existing diversity meets new immigration. Ethnic and Racial Studies, 38(4), 636-649.

4. Alagna, M. (2018). Un altro mondo e possibile secessione e concentrazione. Cambio, 8(15), 15.

5. Alava, S., Frau-Meigs, D., \& Hassan, G. (2017). Youth and violent extremism on social media: mapping the research. UNESCO: Paris.

6. Alba, R., \& Duyvendak, J. W. (2019). What about the mainstream? Assimilation in super-diverse times. Ethnic and Racial Studies, 42(1), 105-124.

7. Ambrosini, M. (2017). Superdiversity, multiculturalism and local policies: A study on European cities. Policy \& Politics, 45(4), 585-603.

8. Aptekar, S. (2019). Super-diversity as a methodological lens: Re-centring power and inequality. Ethnic and Racial Studies, 42(1), 53-70.

9. Aspinall, P.J (2012). Answer formats in british census and survey ethnicity questions: Does open response better capture 'superdiversity'? Sociology, 46(2), 354364.

10. Back, L., \& Sinha, S. (2016). Multicultural conviviality in the midst of racism's ruins. Journal of Intercultural Studies, 37(5), 517-532.

11. Banegas, D. L (2017). Globalization, superdiversity, language learning and teacher education in Brazil. Initial English Language Teacher Education, 177-191. Bloomsbury Academic.

12. Basstanie, J., \& Devillé, A. (2016). From labelling to social aid for immigrants in the 21st century. Cuadernos De Trabajo Social, 29(2), 285.

13. Becci, I. (2018). Religious superdiversity and gray zones in public total institutions. Journal of Religion in Europe, 11(2-3), 123-137.

14. Belling, L., \& de Bres, J. (2014). Digital superdiversity in Luxembourg: The role of luxembourgish in a multilingual facebook group. Discourse, Context \& Media, 4-5, 74-86. 
15. Benson, A. (2019). Migrant teachers and classroom encounters: Processes of intercultural learning. London Review of Education, 17(1), 1-13.

16. Berg, M. L. (2019). Super-diversity, austerity, and the production of precarity: Latin americans in London. Critical Social Policy, 39(2), 184-204.

17. Biehl, K. S. (2015). Spatializing diversities, diversifying spaces: Housing experiences and home space perceptions in a migrant hub of Istanbul. Ethnic and Racial Studies, 38(4), 596-607.

18. Billingsley, B. (2016). Ways to prepare future teachers to teach science in multicultural classrooms. Cultural Studies of Science Education, 11(2), 283-291.

19. Boccagni, P. (2015). (Super) diversity and the migration-social work nexus: A new lens on the field of access and inclusion? Ethnic and Racial Studies, 38(4), 608620.

20. Blommaert, J. \& Varis, P. (2015). Culture as accent: The cultural logic of Hijabista. Semiotica, 203, 153-177.

21. Bouma, G. D., \& Halafoff, A. (2017). Australia's changing religious ProfileRising nones and pentecostals, declining british protestants in superdiversity: Views from the 2016 census. Journal for the Academic Study of Religion, 30(2), 129-143.

22. Brynin, M., Longhi, S., \& Zwysen, W. (2019). The diversification of inequality. The British Journal of Sociology, 70(1), 70-89.

23. Chan, A. (2018). Transnational parenting practices of chinese immigrant families in new zealand. Contemporary Issues in Early Childhood, 19(3), 219-230.

24. Creese, A., \& Blackledge, A. (2010). Towards a sociolinguistics of superdiversity. Zeitschrift Für Erziehungswissenschaft, 13(4), 572.

25. Crul, M. (2016) Strangers no more. Debunking major theoretical assumptions. Ethnic and Racial Studies, 39 (13), 2325-2331.

26. Crul, M. (2018). A new angle to the assimilation debate in the US. Ethnic and Racial Studies, 41(13), 2258-2264.

27. Curry, W. B., Dagkas, S., \& Wilson, M. (2017). Levels and patterns of physical activity and sedentary time among super diverse adolescents in East London: A crosssectional study. Ethnicity \& Health, 22(3), 242-256.

28. De Bock, J. (2015). Not all the same after all? Superdiversity as a lens for the study of past migrations. Ethnic and Racial Studies, 38(4), 583-595. 
29. De Carvalho, R. (2016). Science initial teacher education and superdiversity: Educating science teachers for a multi-religious and globalised science classroom. Cultural Studies of Science Education, 11(2), 253-272.

30. Díaz C.J. (2016). Growing Up Bilingual and Negotiating Identity in Globalised and Multicultural Australia. In: Cole D., Woodrow C. (eds) Super Dimensions in Globalisation and Education. Cultural Studies and Transdisciplinarity in Education, vol 5. Springer, Singapore.

31. Fabricio, B. F. (2014). The empire blogs back: Gendered and sexualized cultural "others" in superdiversified digital trajectories. Discourse, Context \& Media, 4-5, 7.

32. Franklin, C., Kim, J. S., \& Tripodi, S. J. (2009). A meta-analysis of published school social work practice studies: 1980-2007. Research on Social Work Practice, 19(6), 667-677.

33. Gallez, E. (2018). Foreigners and refugees behind bars: How flemish prisons tackle linguistic barriers. The European Legacy, 23(7-8), 738-756.

34. Geldof, D., Schrooten, M., \& Withaeckx, S. (2017). Transmigration: The rise of flexible migration strategies as part of superdiversity. Policy \& Politics, 45(4), 567-584. 35. Gill Thomson, \& Virginia Schmied. (2017). Psychosocial resilience and risk in the perinatal period. London: Routledge Ltd.

36. Goodson, L., \& Grzymala-Kazlowska, A. (2017). Researching migration in a superdiverse society: Challenges, methods, concerns and promises. Sociological Research Online, 22(1), 1-13.

37. Green, G., Davison, C., Bradby, H., Krause, K., Morente Mejías, F., \& Alex, G. (2014). Pathways to care: How superdiversity shapes the need for navigational assistance. Sociology of Health and Illness, 36(8), 1205-1219.

38. Hendriks, P., \& Van Ewijk, H. (2019). Finding common ground: How superdiversity is unsettling social work education. European Journal of Social Work, 22(1), 158-170.

39. Hiroyuki O., Wataru F., Susumu G., \& Minoru K. (2000). A heuristic graph comparison algorithm and its application to detect functionally related enzyme clusters. Nucleic Acids Research, 28(20), 4021-4028.

40. Hochschild, A. R. (2016). Strangers in their own land. Anger and mourning on the American Right. New York: The New Press.

41. Iqbal, H., Neal, S., \& Vincent, C. (2017). Children's friendships in super-diverse localities: Encounters with social and ethnic difference. Childhood, 24(1), 128-142. 
42. Jensen, O. (2017). Superdiversity in the post-industrial city: A comparative analysis of backlash narratives in six European neighborhoods. Policy \& Politics, 45(4), 643-660.

43. Jones, T., Ram, M., \& Theodorakopoulos, N. (2010). Transnationalism as a force for ethnic minority enterprise? The case of Somalis in Leicester. International Journal of Urban and Regional Research, 34(3), 565-585.

44. Juffermans, K., Blommaert, J., Kroon, S., \& Li, J. (2014). Dutch-Chinese repertoires and language ausbau in superdiversity: A view from digital media. Discourse, Context \& Media, 4-5, 48-61.

45. Knowles, C. (2013). Nigerian London: Re-mapping space and ethnicity in superdiverse cities. Ethnic and Racial Studies, 36(4), 651-669.

46. Krishna Sharma, B. (2014). On high horses: Transnational Nepalis and language ideologies on YouTube. Discourse, Context \& Media, 4-5, 19-28.

47. Lamar Prieto, C. (2016). On teaching the history of California Spanish to HLL using Siri: Methodology and procedures. Journal of New Approaches in Educational Research, 5(2), 107-114.

48. Liberali, F. C. (2017). Globalization, Superdiversity, Language Learning and Teacher Education in Brazil. Initial English Language Teacher Education: International Perspectives on Research, Curriculum and Practice. Ed. Darío Luis Banegas. London: Bloomsbury Academic, 177-191. Bloomsbury Education and Childhood Studies.

49. Lindenmeyer, A., Redwood, S., Griffith, L., Teladia, Z., \& Phillimore, J. (2016). Experiences of primary care professionals providing healthcare to recently arrived migrants: A qualitative study. BMJ Open, 6(9), 1-9.

50. López Peláez, A., \& Gómez Ciriano, E.J. (2019). Austerity, social work and welfare policies: a global perspective. Pamplona: Thomson Reuters Aranzadi.

51. Lotherington, H. (2017). Elementary school language and literacy education for civic engagement: An evolving playbook for postmodern times. Language and Literacy, 19(3), 4.

52. Lundahl, B., \& Yaffe, J. (2007). Use of meta-analysis in social work and allied disciplines. Journal of Social Service Research, 33(3), 1-11.

53. Majo, J. (2018). Giving ethnic diversity its spatial and temporal meaning examples from Slovakia. Sociológia, 50(6), $672-696$. 
54. Maly, I. (2016). Detecting social changes in times of superdiversity: An ethnographic linguistic landscape analysis of Ostend in Belgium. Journal of Ethnic and Migration Studies, 42(5), 703-723.

55. Maly, I., \& Varis, P. (2016). The 21st century hipster: On micro-populations in times of superdiversity. European Journal of Cultural Studies, 19(6), 637-653.

56. Martínez, M. A., Herrera, M., Contreras, E., Ruiz, A., \& Herrera-Viedma, E. (2015). Characterizing highly cited papers in Social Work through HClassics. Scientometrics, 102(2), 1713-1729.

57. Mc Laughlin, F. (2014). Senegalese digital repertoires in superdiversity: A case study from seneweb. Discourse, Context \& Media, 4-5, 29-37.

58. Medda-Windischer, R. (2017). Superdiversity and sub-national autonomous regions: Perspectives from the south tyrolean case. Policy \& Politics, 45(4), 547-566.

59. Meissner, F. (2015). Migration in migration-related diversity? The nexus between superdiversity and migration studies. Ethnic and Racial Studies, 38(4), 556567.

60. Meissner, F. (2018). Legal status diversity: Regulating to control and everyday contingencies. Journal of Ethnic and Migration Studies, 44(2), 287-306.

61. Moorhead, S. A., Hazlett, D. E., Harrison, L., Carroll, J. K., Irwin, A., \& Hoving, C. (2013). A new dimension of health care: systematic review of the uses, benefits, and limitations of social media for health communication. Journal of medical Internet research, 15(4), e85.

62. Neal, S., Channon, A. A., Carter, S., \& Falkingham, J. (2015). Universal health care and equity: evidence of maternal health based on an analysis of demographic and household survey data. International journal for equity in health, 14(1), 56.

63. Neyrinck, J. (2017). Intangible cultural heritage in times of 'superdiversity': Exploring ways of transformation. International Journal of Intangible Heritage, 12, 158.

64. Ní Shé É., Joye R. (2018). The Health Systems Workforce in an Era of Globalised Superdiversity-Exploring the Global Care Chain Landscape in Ireland. Chapter 8. Springer International Publishing

65. Oliveira, N., \& Padilla, B. (2017). Integrating superdiversity in urban governance: The case of inner-city Lisbon. Policy \& Politics, 45(4), 605-622.

66. Oosterlynck, S., Schuermans, N., \& Loopmans, M. (2017). Place, diversity and solidarity. London; New York: Routledge. 
67. Padilla, B., Azevedo, J., \& Olmos-Alcaraz, A. (2015). Superdiversity and conviviality: Exploring frameworks for doing ethnography in southern European intercultural cities. Ethnic and Racial Studies, 38(4), 621-635.

68. Padilla, B., Olmos Alcaraz, A., \& Azevedo, J. (2018). Etnografías de la convivialidad y superdiversidad: Reflexiones metodológicas. Andamios, Revista De Investigación Social, 15(36), 15.

69. Pemberton, S., \& Phillimore, J. (2018). Migrant place-making in super-diverse neighbourhoods: Moving beyond ethno-national approaches. Urban Studies, 55(4), 733750.

70. Phillimore, J. (2013). Housing, home and neighbourhood renewal in the era of superdiversity: Some lessons from the west midlands. Housing Studies, 28(5), 682-700.

71. Phillimore, J. (2015). Delivering maternity services in an era of superdiversity: The challenges of novelty and newness. Ethnic and Racial Studies, 38(4), 568-582.

72. Phillimore, J. (2016). Migrant maternity in an era of superdiversity: New migrants' access to, and experience of, antenatal care in the west midlands, UK. Social Science \& Medicine, 148, 152-159.

73. Phillimore, J., Bradby, H., Knecht, M., Padilla, B., Brand, T., Cheung, S. Y., Pemberton, S. \& Zeeb, H. (2015). Understanding healthcare practices in superdiverse neighbourhoods and developing the concept of welfare bricolage: Protocol of a crossnational mixed-methods study. BMC International Health and Human Rights, 15(1), 16. 74. Phillips, T., \& Webber, R. (2014). Superdiversity and the browning of labour. The Political Quarterly, 85(3), 304-311.

75. Poole, M. (2016). The feasibility of educating trainee science teachers in issues of science and religion. Cultural Studies of Science Education, 11(2), 273-281.

76. Ramsey, A. T., \& Montgomery, K. (2014). Technology-based interventions in social work practice: A systematic review of mental health interventions. Social work in health care, 53(9), 883-899.

77. Righard, E. (2018). Conceptualising social work through the lens of transnationalism. Nordic Journal of Migration Research, 8(4), 245-253.

78. Ritchie, J. (2016). Qualities for early childhood care and education in an age of increasing superdiversity and decreasing biodiversity. Contemporary Issues in Early Childhood, 17(1), 78-91.

79. Rutten, K. (2017). No strings attached: Exploring the relationship between anthropology and contemporary arts. Critical Arts, 31(2), 1-11. 
80. Scholten, P. (2018). Beyond migrant integration policies: Rethinking urban governance of migration-related diversity. Hrvatska i Komparativna Javna Uprava: Časopis Za Teoriju i Praksu Javne Uprave, 18(1), 7-30.

81. Seilstad, B. (2018). Partially shared objects and the (elusive) potential of expansive learning: The case of "jury" in community-based citizenship classes for nepali-speaking bhutanese refugee elders. Mind, Culture, and Activity, 25(4), 308.

82. Sepulveda, L., Syrett, S., \& Lyon, F. (2011). Population superdiversity and new migrant enterprise: The case of London. Entrepreneurship \& Regional Development, 23(7-8), 469-497.

83. Schuermans, N.; \& Debruyne, P. (2017). Learning to cope with superdiversity. Place-based solidarities at a (pre-) primary Catholic school in Leuven, Belgium. Place, Diversity and Solidarity. Chapter 3. ImprintRoutledge, London.

84. Siebers, H. (2018). Does the superdiversity label stick? Configurations of ethnic diversity in Dutch classrooms. International Sociology, 33(6), 674-691.

85. Social Work and Research in Advanced Welfare States (2017). Edited By Kjeld Hogsbro, Ian F Shaw. London: Routledge Ltd.

86. Spoonley, P. (2015). New diversity, old anxieties in New Zealand: The complex identity politics and engagement of a settler society. Ethnic and Racial Studies, 38(4), 650-661.

87. Stringer, M. D. (2014). Evidencing superdiversity in the census and beyond. Religion, 44(3), 453-465.

88. Taboadela, O., Maril, M., \& Lamela, C. (2018). La superdiversidad migratoria en el medio rural: Odemira, Alentejo, un estudio de caso. Finisterra - Revista Portuguesa De Geografia, (107), 87-105.

89. Trienekens, S., \& Groot, C. (2016). Age included on music, generations, diversity and freedom. Amsterdam: SWP Publishers.

90. Van Breugel, I., \& Scholten, P. (2017). Mainstreaming in response to superdiversity? The governance of migration-related diversity in France, the UK and the Netherlands. Policy \& Politics, 45(4), 511-526.

91. Van de Vijver, F.J.R., Blommaert, J.M.E., Gkoumasi, G., Stogianni, M. (2015). On the need to broaden the concept of ethnic identity. International Journal of Intercultural Relations, 46(1), 36-46. 
92. Van Robaeys, B., Raeymaeckers, P., \& Ewijk, H. v. (2017). Contextualtransformational social work in superdiverse contexts: An evaluatie perspective by clients and social workers. Qualitative Social Work, 17 (5), 676-691.

93. Van Robaeys, B., Van Ewijk, H., \& Dierckx, D. (2018). The challenge of superdiversity for the identity of the social work profession: Experiences of social workers in 'De sloep' in ghent, belgium. International Social Work, 61(2), 274-288.

94. Vertovec, S. (2007). Super-diversity and its implications. Ethnic and racial studies, 30(6), 1024-1054.

95. Wagner, L. (2017). Flirting diasporically: Visits 'home' facilitating diasporic encounters and complex communities. Journal of Ethnic and Migration Studies, 44:2, 321-340.

96. Wekker, F. (2019). "We have to teach them diversity": On demographic transformations and lived reality in an Amsterdam working-class neighbourhood. Ethnic and Racial Studies, 42(1), 89.

97. Wessendorf, S. (2014). Commonplace diversity: Social relations in a superdiverse context. Springer.

98. Wilson, W. J. (2011). When work disappears: The world of the new urban poor. Vintage.

99. Wladyka D., Morén-Alegret R. (2018) A Sustainable Touristic Place in Times of Crisis? The Case of Empuriabrava-A Superdiverse Mediterranean Resort. In: Leal Filho W., Marans R., Callewaert J. (eds) Handbook of Sustainability and Social Science Research. World Sustainability Series. Springer, Cham.

100. Yanasmayan, Z. (2016). Does education 'trump' nationality? Boundary-drawing practices among highly educated migrants from turkey. Ethnic and Racial Studies, 39(11), 2041-2059. 
Appendix. Table 1. Causes of superdiversity

\section{CAUSES of the SUPERDIVERSITY}

Authors

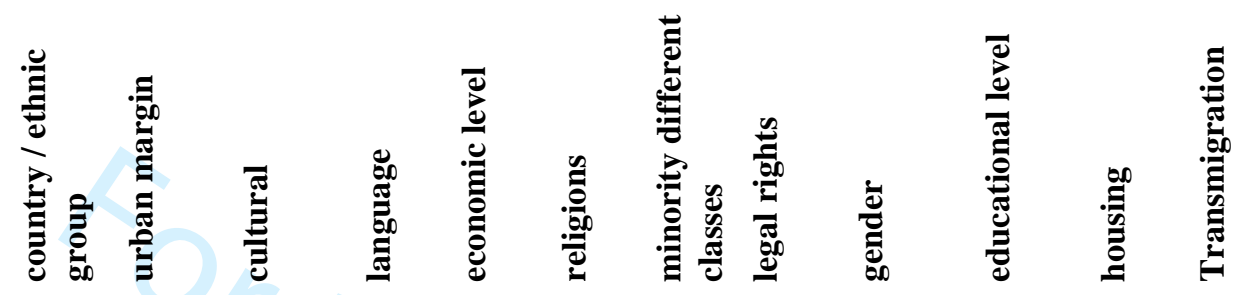

LEVEL 1

Bouma \& Halafoff (2017)

Brynin et al. (2019)

Curry et al. (2017)

Majo (2018)

Meissner (2017)

Phillimore et al. (2015)

Phillips \& Webber (2014)

Stringer (2014)

\section{LEVEL 3}

Pemberton \& Phillimore (2018)

\section{LEVEL 4}

Abdou \& Geddes (2017)

Aceska et al. (2019)

Acosta-García \& Martínez-Ortiz 
(2015)

Alba \& Duyvendak (2019)

X X

Ambrosini (2017)

$\mathrm{x}$

$x$

$\mathrm{X}$

Aptekar (2019)

Aspinall (2012)

Back \& Sinha (2016)

Belling \& de Bres (2014)

Berg (2019)

Biehl (2015)

Billingsley (2016)

Blommaert \& Varis (2015)

Chan (2018)

De Bock (2015)

Díaz (2016)

Fabricio (2014)

Gallez (2018)

Geldof et al. (2017)

Green et al. (2014)

Hendriks \& van Ewijk (2019)

Jensen (2017)

Jones et al. (2010)

Juffermans et al. (2014)

Knowles (2013)

Mc Laughlin (2014)

Lindenmeyer et al. (2016)

Maly \& Varis (2016)

Oliveira \& Padilla (2017)

Padilla et al. (2015)

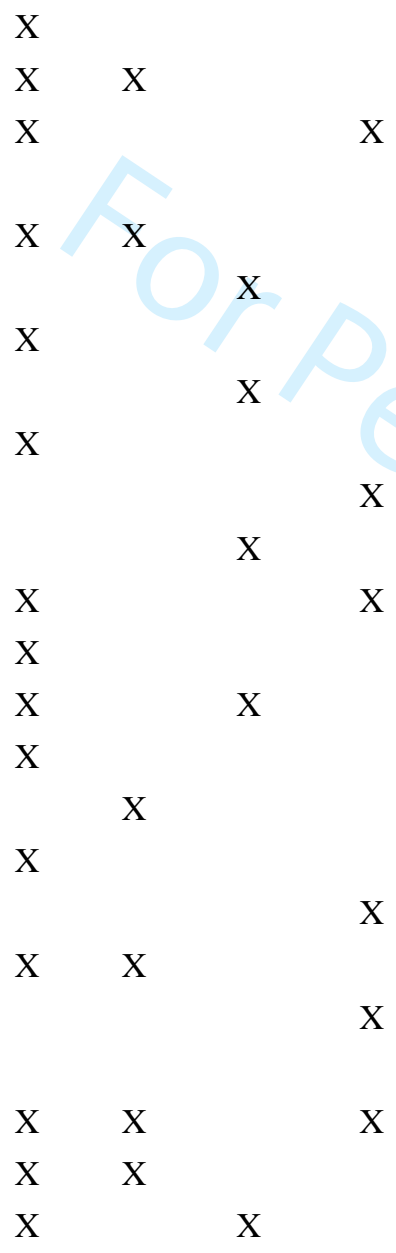

$\mathrm{X}$

$\mathrm{X}$

X

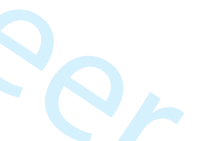

$\mathrm{X}$

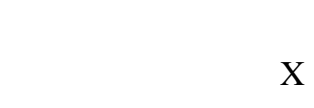

$\mathrm{X}$

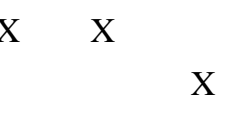

$\mathrm{X}$

$\mathrm{X}$ 
Padilla et al. (2018)

Phillimore (2016)

Phillimore (2015)

X X

Phillimore (2013)

Scholten (2018)

Schuermans \& Debruyne (2017)

Seilstad (2018)

Sepulveda et al. (2011)

Krishna Sharma (2014)

Siebers (2018)

Spoonley (2015)

Taboadela et al. (2018)

Van Breugel \& Scholten (2017)

Van de Vijver et al. (2015)

Van Robaeys et al.(2018)

Wagner (2017)

Wekker (2019)

Wladyka \&Morén-Alegret (2018)

Yanasmayan (2016)

$$
\mathrm{X}
$$

\section{LEVEL 5}

Basstanie \& Devillé (2016)

Becci (2018)

Benson (2019)

Boccagni (2015)

Crul (2016)

Crul (2018)

De Carvalho (2016)

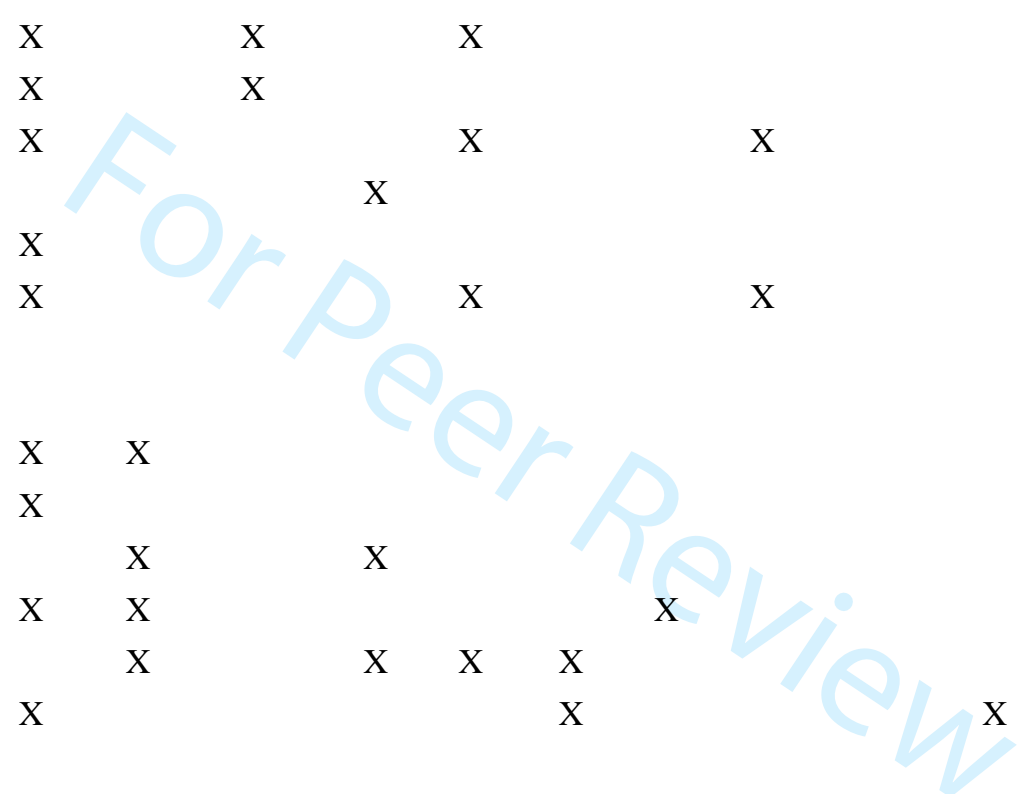

$\mathrm{X}$

$$
\text { X }
$$

X
$\mathrm{X}$ 


\section{Díaz (2016)}

Goodson \& Grzymala-Kazlowska (2017)

Iqbal et al.(2017)

Liberali (2017)

Medda-Windischer (2017)

Meissner (2015)

Neyrinck (2017)

Ni Shé \& Joye (2018)

Poole (2016)

Righard (2018)

TOTAL

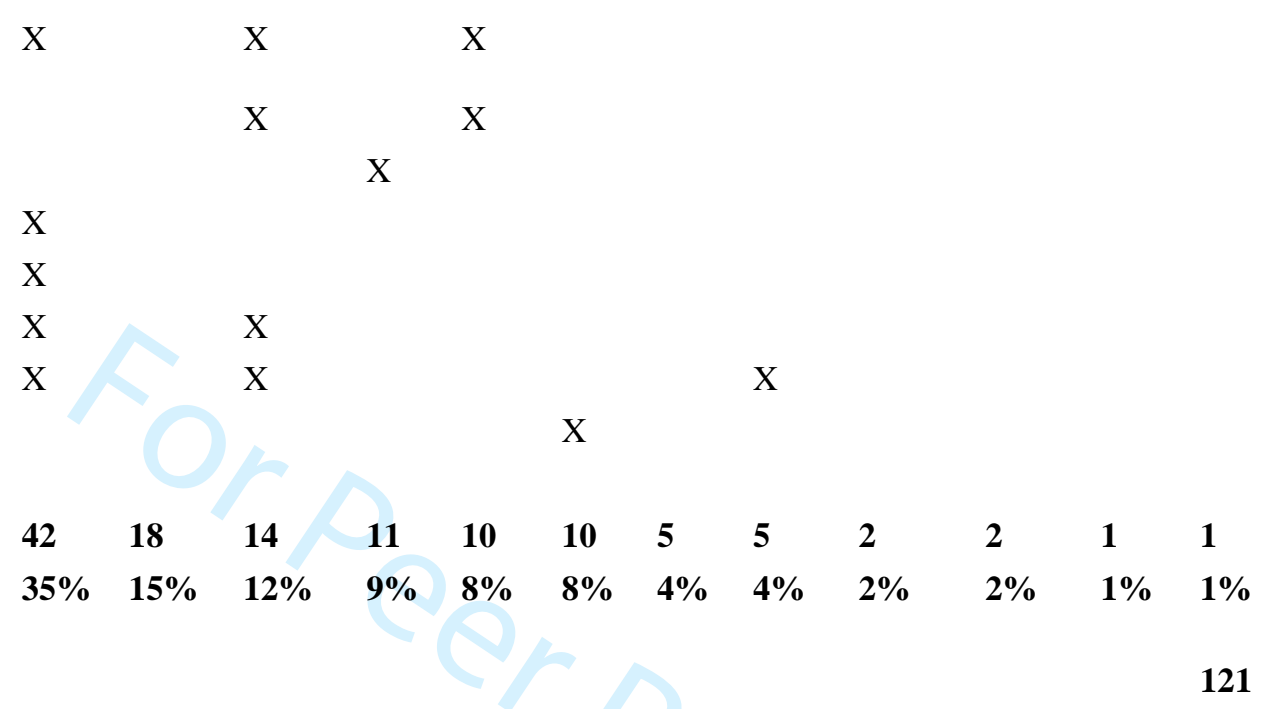

Note: "total" refers to the number of articles that use one of the sources of superdiversity (e.g., religions, cultural, gender, etc.). Each article can be classify in more than one item. 
Appendix.Table 2. Implemented policies

Implemented policies

Authors

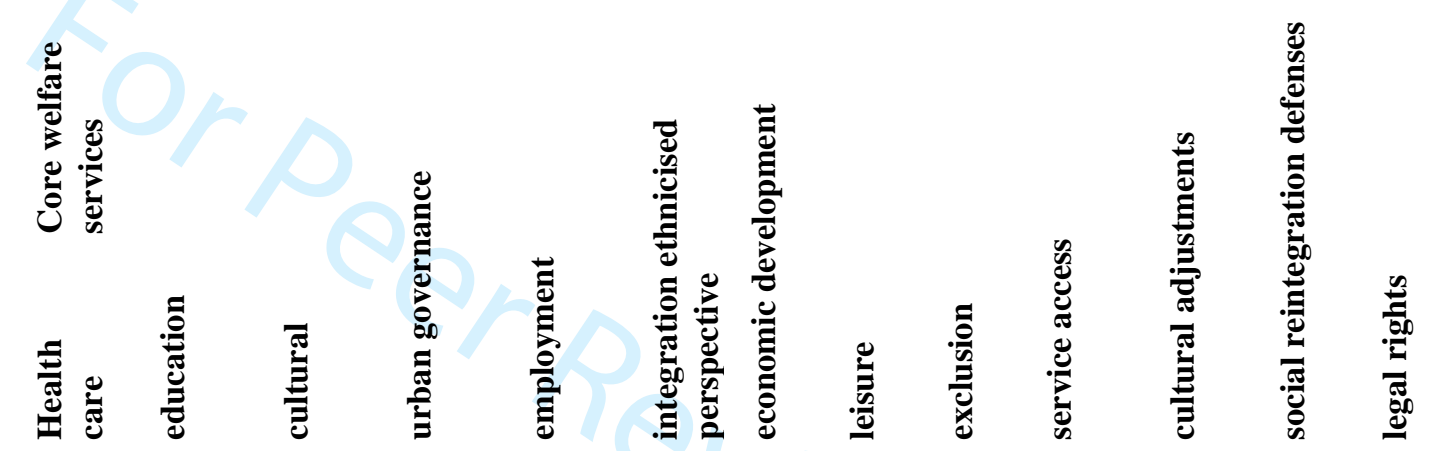

\section{LEVEL 1}

Bouma \& Halafoff (2017)

Brynin et al. (2019)

Curry et al. (2017)

Majo (2018)

Meissner (2017)

Phillimore et al. (2015)

Phillips \& Webber (2014)

Stringer (2014)

$\mathrm{X}$

$\mathrm{X}$

X $\quad \mathrm{X}$

$\mathrm{X}$

$\mathrm{X}$ 
Authors

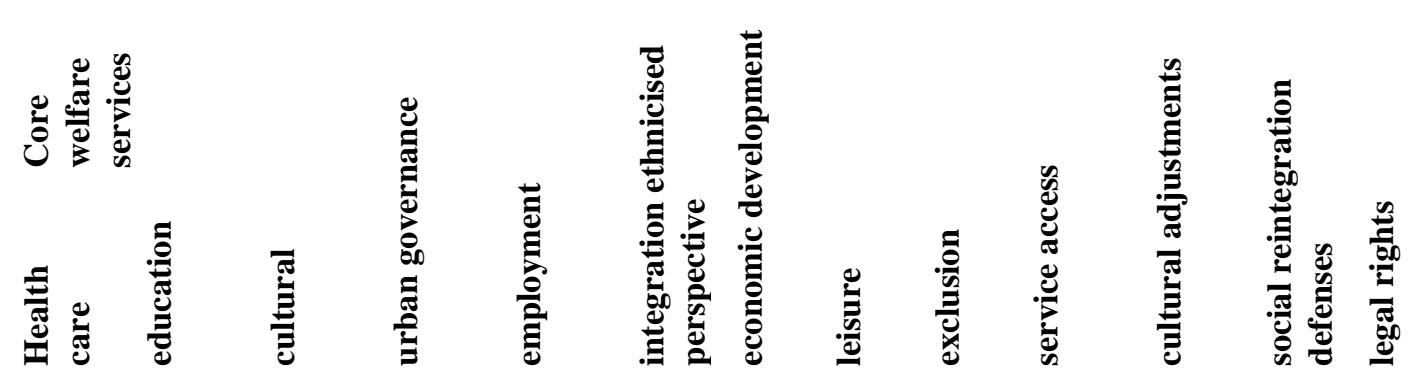

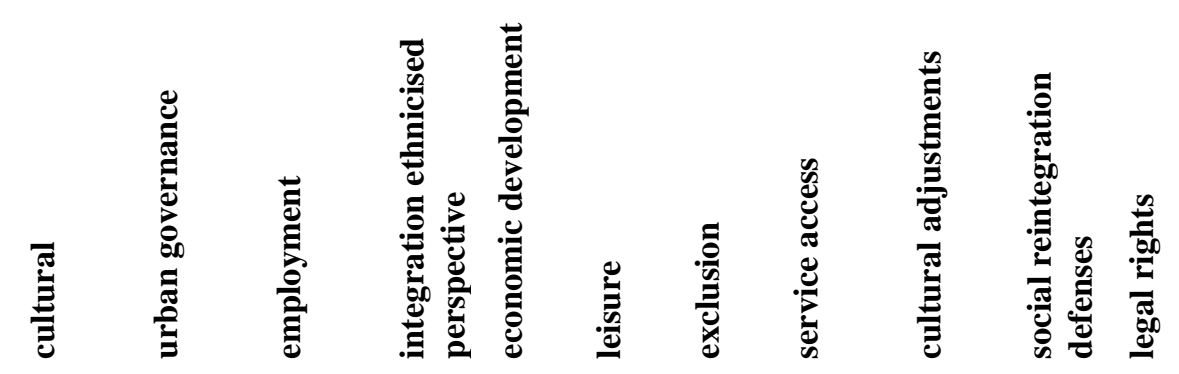

\section{LEVEL 3}

Pemberton \& Phillimore (2018)

\section{LEVEL 4}

Abdou \& Geddes (2017)

Aceska et al. (2019)

Acosta-García \&MartínezOrtiz (2015)

Alba \& Duyvendak (2019)

Ambrosini (2017)

Aptekar (2019)

Aspinall (2012)

Back \& Sinha (2016)

Belling \& de Bres (2014)

Berg (2019)

Biehl (2015)

Billingsley (2016)

$\mathrm{X}$

$\mathrm{X}$

X

$\mathrm{X}$

X

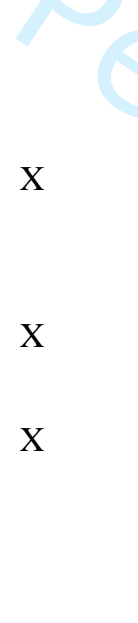


Blommaert \& Varis (2015)

Chan (2018)
De Bock (2015)

Díaz (2016)

Fabricio (2014)

Gallez (2018)

Geldof et al. (2017)

Green et al. (2014)

Hendriks \& van Ewijk

(2019)

Jensen (2017)

Jones et al. (2010)

Juffermans et al.(2014)

Knowles (2013)

Mc Laughlin (2014)

Lindenmeyer et al.(2016)

Maly \&Varis (2016)

Oliveira \& Padilla (2017)

Padilla et al. (2015)

Padilla et al. (2018)

Phillimore (2016)

Phillimore (2015)

Phillimore (2013)

Scholten (2018)

Schuermans \& Debruyne

Seilstad (2018)

Sepulveda et al.(2011)

Krishna Sharma (2014)
X

$\mathrm{X}$

$\mathrm{X}$

$\mathrm{X}$

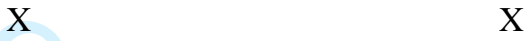

X

$\mathrm{X}$

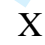

X

X

X

X X

$\mathrm{X}$

X

$\mathrm{X}$

X

$\mathrm{X}$

X

$\mathrm{X}$

$\mathrm{X}$ 
Taboadela et al. (2018)

Van Breugel \& Scholten

(2017)

Van de Vijver et al.(2015)

van Robaeys

X

Van Robaeys et al. (2018) X

Wagner (2017)

Wekker (2019)

Wladyka \& Morén-Alegret (2018)

Yanasmayan (2016)

\section{LEVEL 5}

Basstanie \& Devillé

(2016)

Becci (2018)

Benson (2019)

Boccagni (2015)

Crul (2016)

Crul (2018)

De Carvalho (2016)

Díaz (2016)

Goodson \& Grzymala-

Kazlowska (2017)

Iqbal et al.(2017)

Liberali (2017)

Medda-Windischer (2017) X

Meissner (2015)

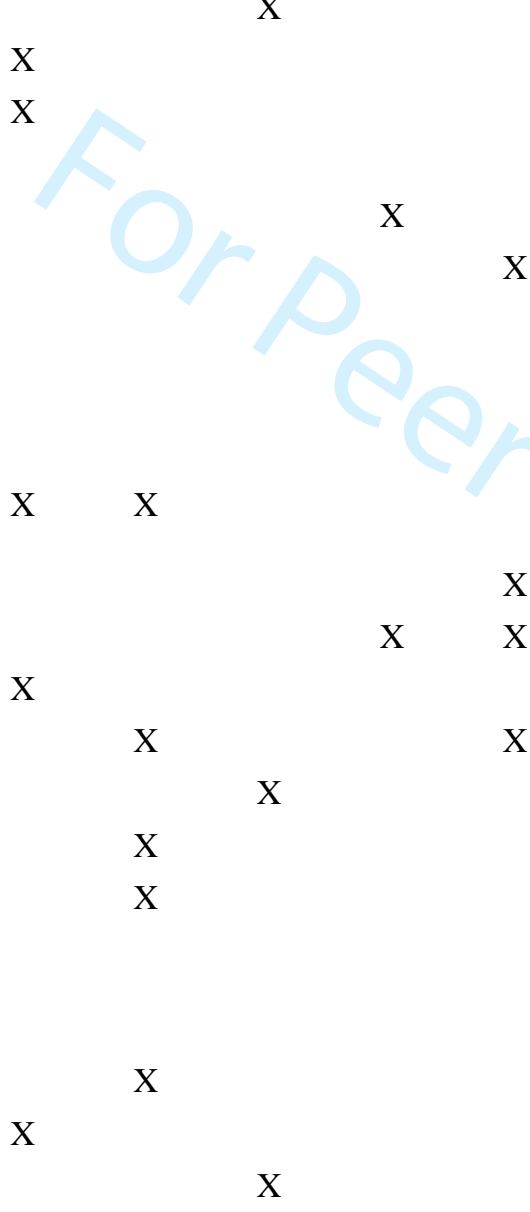


Neyrinck (2017)

Ni Shé \& Joye (2018)

Poole (2016)

Righard (2018)

TOTAL
$\mathrm{X}$

$\begin{array}{lllllllllllll}X & X & & & & & & & & & & & \\ & X & & & & & & & & & & & \\ X & & & & & & & & & & & X & \\ 17 & 14 & 14 & 11 & 12 & 3 & 2 & 1 & 1 & 1 & 1 & 1 & 1 \\ 22 \% & 18 \% & 18 \% & 14 \% & 15 \% & 4 \% & 3 \% & 1 \% & 1 \% & 1 \% & 1 \% & 1 \% & 1 \% \\ & & & & & & & & & & & & 79\end{array}$

Note: "total" refers to the policies proposed in each article (e.g., health care, education, cultural, etc.). Each article can be classify in more than one item. 